\title{
Theological Concept of the Fourth Gospel in the Context of Jesus' Glorification Prayer (Jn 17:1-5)
}

\begin{abstract}
The analysis of Jn 17:1-5 in its textual, literary, exegetical and theological dimensions shows the importance of Jesus' prayer to His Father. The prayer of glorification includes a deep theological perspective expressed by the connection between the Son and the Father, earth and Heaven, the believers and God. The glorification of the Father in the prayer of the Son obtains its dynamism in the glorification of the Son in the realization of the Hour. The concept of the Johannine Hour reveals its eschatological character which can be fulfilled in the Passion, Death and Resurrection of the Son. The prayer of Jesus opens the Heaven for every person who together with Him can fulfill the will of God. In the glorification of the Father by the Son (earthly glorification) and the Son by the Father (heavenly glorification) the believers obtain eternal life in the Heavenly Love of God.
\end{abstract}

\section{Keywords}

Glorification prayer, Johannine theology, eschatology.

The beginning of the prayer of glorification, in which Jesus addresses the Father directly (Jn 17:1-5), in the theological perspective, constitutes one of the most important places in John's Gospel. ${ }^{2}$ In the text we can discover not only the depth

1 This article was written as the realization of the research project n. 2014/15/B/HS1/03866 with financial support of National Science Centre.

${ }^{2}$ See. E. Käsemann, Jesu letzter Wille nach Johannes 17, Tübingen 1971; F. Gryglewicz, Modlitwa Arcykapłańska, in: Egzegeza Ewangelii św. Jana, ed. F. Gryglewicz, Lublin 1992, p. 113- 
of the relationships between the Father and the Son, but we can also recognize how temporal things are related to transcendence. At the very beginning of the prayer Jesus raises his eyes from the earth to heaven and asks to be glorified by his Father (v. 1). He repeats his request in v. 5. At the same time he assures his Father that has glorified him on the earth by completing the work that he was given to do (v. 4). What glorification does he ask his Father for? How is Father glorified by Jesus in worldly terms? What does the eschatological glorification of the Father and the Son consist of? How can the disciples of Jesus participate in the glorification of the Father and the Son?

Searching for the answers to these questions becomes the subject of this present article. As the result of conducting a literary and exegetical analysis of the first part of the prayer of Jesus (Jn 17:1-5) it will be possible to embark on a deeper theological context of the Fourth Gospel. In such a perspective it will be possible to recognize the intention of the inspired author, who conveys to us God's saving ideas present in the Fourth Gospel.

\section{Textual analysis of Jn 17:1-5}

Below presented is the original text of Jn 17:1-5 along with its English translation:

\begin{tabular}{|c|c|}
\hline Text Jn 17:1-5 & Translation \\
\hline 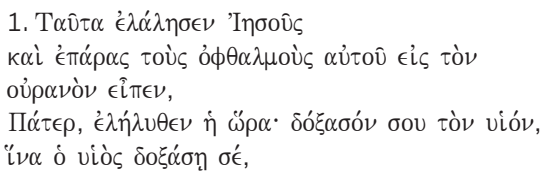 & $\begin{array}{l}\text { 1. These things Jesus spoke; } \\
\text { and then lifting up his eyes } \\
\text { to heaven, he said, } \\
\text { "Father, the Hour has come; glorify your Son, } \\
\text { that the Son may glorify you, }\end{array}$ \\
\hline 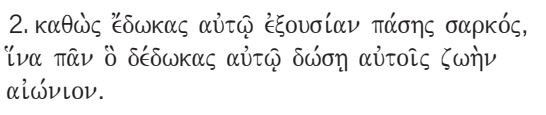 & $\begin{array}{l}\text { 2. even as you gave him authority over all flesh, } \\
\text { that to all whom you have given him, he may } \\
\text { give eternal life. }\end{array}$ \\
\hline 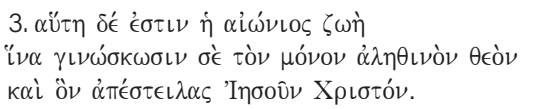 & $\begin{array}{l}\text { 3. And this is eternal life, } \\
\text { that they may know you, the only true } \\
\text { God, and Jesus Christ whom you have sent. }\end{array}$ \\
\hline
\end{tabular}

146; D. F. Tolmie, Jesus' Farewell to the Disciples: John 13:1-17:26 in Narratological Perspective, Leiden 1995; H. W. Attridge, How priestly is the 'high priestly prayer' of John 17?, "Catholic Biblical Quarterly" 75 (2013), p. 1-14; M. P. Hera, Christology and discipleship in John 17, Tübingen 2013. 


\begin{tabular}{|c|c|}
\hline Text Jn 17:1-5 & Translation \\
\hline 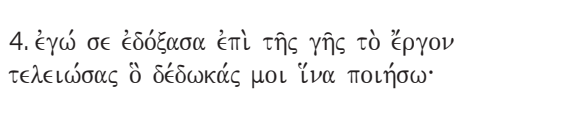 & $\begin{array}{l}\text { 4. I glorified you on the earth, having accom- } \\
\text { plished the work which you have given me } \\
\text { to do. }\end{array}$ \\
\hline 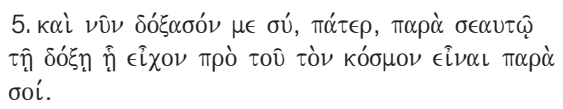 & $\begin{array}{l}\text { 5. And now, you glorify me together with your- } \\
\text { self, Father, with the glory which I had with } \\
\text { you before the world was. }\end{array}$ \\
\hline
\end{tabular}

In v. 1 in some manuscripts (A D Q and other) after noun viós there is the pronoun $\sigma o v$. Other manuscripts $\left(\mathrm{C}^{3} \mathrm{~L} \Delta \Psi\right.$ and others) add the conjunction $\kappa \alpha \iota$ before vióc. It seems that the pronoun and the conjunction may have been added by copiers for the sake of greater clarity of the text. The shorter variant confirmed by important manuscripts $\left(\mathrm{P}^{60} \times \mathrm{B} \mathrm{C}^{\star} \mathrm{W}\right.$ and other) is more justified.

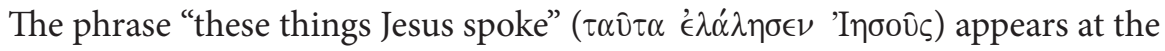
end of Jesus' farewell speeches to his disciples and it takes us to a new stage of the realization of the Hour and his passage to the Father. We take this fact into consideration in our translation by using the wording "and then". In the translation the term "Hour" is spelt with a capital letter due to its specificity and rich theological content in John's Gospel.

In v. 2 in the phrase $\iota \nu \alpha \pi \hat{\alpha} \nu$ we find the neuter singular, which takes on a collective meaning and refers to all those who God gave to Jesus. The phrase

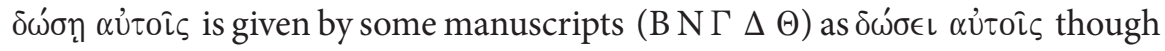
the use of the future tense after $i \nu \alpha$ seems foreign to John's style. We come across

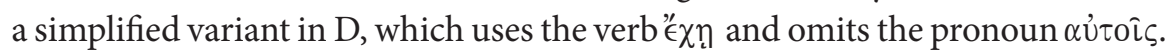

Many prominent exegetes consider v. 3 to be a later editorial addition. ${ }^{3}$ Certainly one can agree with those who point out the textual difficulty resulting from the emergence of the definition of eternal life in Jesus' direct prayer to His Father. The official title "Jesus Christ" uttered by Jesus himself may also seem surprising. This line of argument is supported also by the analysis of the style in v. 3 , as a result of which we can conclude that the phrase "the only true God" does not occur in any other place in John's Gospel. Also, the phrase "eternal life" ( $\dot{\eta} \alpha i \omega \nu$ เo $\zeta \omega \eta \dot{)}$ ), in which the adjective preceded by an article comes first,

3 See: M.-J. Lagrange, Évangile selon Saint Jean, Paris 1925, p. 440-441; J. H. Bernard, A Critical and Exegetical Commentary on the Gospel According to St. John, vol. 2, Edinburgh 1949, p. 561; R. Bultmann, The Gospel of John, Philadelphia 1971, p. 494-495; R. Brown, The Gospel according to John, vol. 2, London 1971, p. 741. 752-753; M. É. Boismard - A. Lamouille, L'évangile de Jean, Paris 1977, p. 392; R. Schanckenburg, The Gospel according to St. John, vol. 3, London 1982, p. 172-173; G. R. Beasley-Murray, John, Nashville 1999, p. 296-297. 
is not typical of the style of John's Gospel, where a noun usually precedes an adjective and there is no article. ${ }^{4}$ It seems that the final editor of John's Gospel may have been inspired by the text from 1 Jn 5:20, in which we find many parallel wordings: ${ }^{5}$

\begin{tabular}{|c|c|}
\hline In $17: 3$ & 1 Jn 5:20 \\
\hline 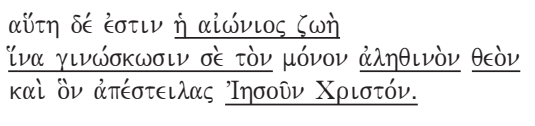 & 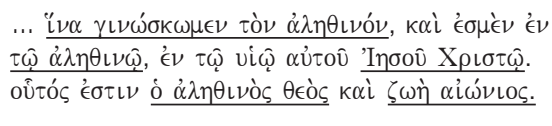 \\
\hline Translation: & Translation: \\
\hline $\begin{array}{l}\text { And this is eternal life, } \\
\text { that they may know you, the only true } \\
\underline{\text { God, and Jesus Christ whom you have sent. }}\end{array}$ & $\begin{array}{l}\text {... in order that we might know Him who is } \\
\text { true, and we are in Him who is true, in His } \\
\text { Son Jesus Christ. This is the true God and } \\
\text { eternal life. }\end{array}$ \\
\hline
\end{tabular}

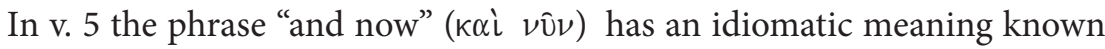
already in the Old Testament texts as וְעתו. It occurs in particular in a liturgical and juridical context and indicates the content based on facts known earlier. ${ }^{6}$

\section{The structure of Jn 17:1-5}

Most exegetes agree with regard to the division of the first part of the prayer between verse 5 and $6{ }^{7}$ Verse 1 and 5 form an inclusion as they both contain the term "Father", a time-related wording ("the Hour has come", "and now"), as well as the same request of Jesus ("glorify your Son", "glorify you me"):

v. 1: Father, the Hour has come; glorify your Son, that the Son may glorify you.

${ }^{4}$ See: Jn 3:15.16.36; 4:14.36; 5:24; 6:27.40.47.54.68; 12:50; 17:2.

${ }^{5}$ See the analysis of M. É. Boismard - A. Lamouille, L'évangile de Jean, p. 392 and of R. Schanckenburg, The Gospel according to ST. John, p. 172.

${ }^{6} \mathrm{~J}$. Becker, Aufbau, Schichtung und theologiegeschichtliche Stellung des Gebetes in Johannes 17, "Zeitschrift für die neutestamentliche Wissenschaft" 60 (1969), p. 209-232.

7 See: M.-J. Lagrange, Évangile selon Saint Jean, p. 439; R. Schnackenburg, Strukturanalyse von Joh 17, "Biblische Zeitschrift" 17 (1973), p. 67-78; L. Stachowiak, Modlitwa arcykapłańska (J 17). Refleksja egzegetyczna, "Roczniki Teologiczno-Kanoniczne" 21 (1974) 85-94; F. Manns, L'Évangile de Jean à la lumière du Judaïsme, Jérusalem 1991, p. 383-400; F. Gryglewicz, Modlitwa Arcykapłańska, in: Egzegeza Ewangelii św. Jana, p. 113-146; T. L. Brodie, The Gospel according to John. A Literary and Theological Commentary, Oxford 1993, p. 508; X. Léon-Dufour, Lecture de l'évangile selon Jean, vol. 3, Paris, p. 279-287; G. R. Beasley-Murray, John, p. 295-296. 
v. 5: And now, you glorify me together with yourself, Father, with the glory which I had with you before the world was.

In Jn 17:1-5 it is possible to isolate a chiastic structure: ${ }^{8}$

A - Father, the Hour has come; glorify your Son (v. 1a)

B - that the Son may glorify you (v. 1b)

$\mathrm{C}$ - even as you gave him authority over all mankind, that to all whom you have given him, he may give eternal life (v. 2)

B' - I glorified you on the earth, having accomplished the work which you have given me to do (v. 4)

$A^{\prime}$ - And now, glorify you me together with yourself, Father, with the glory which I had with you before the world was (v. 5)

Sections A - A' express Jesus' request for an eschatological glorification addressed to God. Sections B - B' express the glorification of the Father by the Son and section $\mathrm{C}$ placed in the center of the text expresses the relationship of the Son to the disciples.

\section{The context and literary genre of Jn 17:1-5}

The text of Jn 17:1-5 constitutes the beginning of the prayer in which Jesus directly addresses His Father. Further on in the prayer, Jesus prays for His disciples (Jn 17:6-19) and for His future followers (Jn 17:20-26). The prayer puts an end to the textual block describing the teaching of Jesus during the Last Supper (Jn 13-17), which - in terms of the literary genre - is identified as Farewell Speech(es). ${ }^{9}$ The prayer is immediately followed by a description of the events connected with the passion of Jesus Christ. Unlike the earlier part of the Gospel (the Book of Signs - chapters 1-12) Farewell Speech(es) do not fall within the public ministry of Jesus, but they are addressed directly to His disciples. Jesus turns to His disciples so as to explain to them the meaning of His life, and prepare them for the parting and for His glory to triumph again. In literary terms the arrangement of speech(es) is typical of John. It is far from contemporary semantics. The idea develops concentrically and the same theme enriched by new aspects occurs repeatedly. They sometimes encompass repetitions or

${ }^{8}$ See: M. É. Boismard - A. Lamouille, L'évangile de Jean, p. 395; F. Manns, L'évangile de Jean à la lumière du Judaïsme, p. 386.

9 Other designations: Testament Speech(es), Consolation Speech(es). 
inclusions of apparently detached ideas. There are frequent transitions from past events to the apocalyptic. In the genre of Farewell Speech(es) it is possible to identify a characteristic structure which emphasizes the importance of the person of Jesus who:

a. gathers His disciples around Him before His death. ${ }^{10}$

b. passes on His advice and promises to His disciples - teaches about the commandment of love ${ }^{11}$, calls for faith (Jn 14:1), sends His disciples to bear fruit (Jn 15:16), to be His witnesses (Jn 15:27), promises to them the Spirit of Truth ${ }^{12}$ and a place in his Father's house (Jn 14:2-3).

c. presents Himself as the One who has done everything He demands of His disciples. ${ }^{13}$

d. announces that the disciples will be upset because of His leaving, that they will be persecuted because the world will come to hate them (Jn 15:18-25). The persecution is presented in a specific way as exclusion from the Synagogue (Jn 16:2). However, the sorrow will turn into joy when the disciples see the Lord again (Jn 16:20).

Thanks to the literary genre the author of the Fourth Gospel emphasizes the theological meaning of the last days of Jesus on earth. By emphasizing the continuation of the history of salvation Jesus is included among the great messengers of God (Moses, David). He embraces the whole of His life, aware of His mission and imminent leaving of this world. Faced with sorrow and dangers lurking for His disciples He tries to remedy the critical situation. When He gives the commandment of mutual love He gives Himself as an example to follow. The prayer of Jesus which is the culmination of the speeches of Jesus (chapter 17), is a reference to ancient prayers. ${ }^{14}$ Many New Testament texts also include mentions of Jesus praying at dramatic or important moments of His life. ${ }^{15}$ The motives of the Farewell Speech(es) are revealed in chapters 13 and 17. Their instructive character can be seen here. These are instructions of the last hour (ultimate things). The instructions are the wisdom of great men who when leaving this world - want to pass this wisdom on to those who are staying.

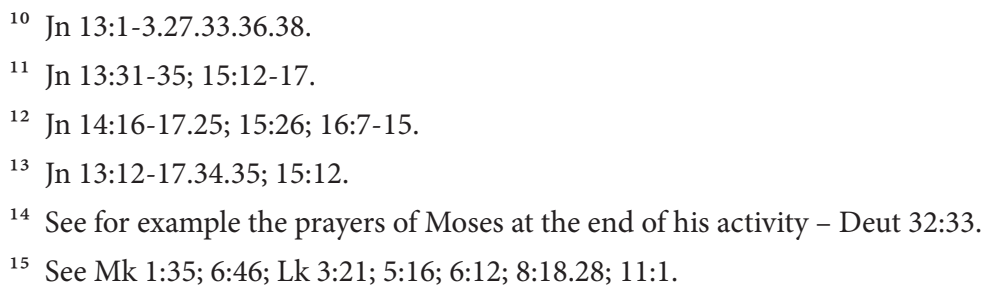


When making His speeches, Jesus covers the past, the present and the future. The prayer of Jesus undoubtedly constitutes the culmination of His teachings.

\section{Exegetic analysis Jn 17:1-5}

v. 1: "These things Jesus spoke; and then lifting up his eyes to heaven, he said, "Father, the Hour has come; glorify your Son, that the Son may glorify you".

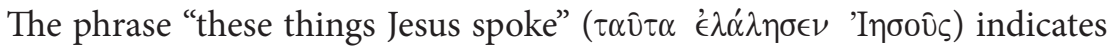
the words of Jesus addressed to His disciples. In the section directly preceding chapter 17, Jesus tells His disciples about His going away to the Father and their being scattered because of persecutions (Jn 16:28-33). A similar wording with a verb in aorist occurs in the Gospel of John only once (Jn 12:36) ${ }^{16}$, where it expresses the completion of a certain stage (the public ministry of Jesus) and the start of something new (the Farewell Speech(es) of Jesus to the disciples He gathered around Him start from Jn 13:1 after Jn 12:36). Also, in Jn 17:1 the phrase seems to put an end to the stage of the Farewell Speech(es) and it introduces a new stage of the way to the Father. The new perspective can also be seen in the change of the audience of the words of Jesus. So far Jesus' disciples have been His listeners, whereas from Jn 17:1 onwards Jesus directly addresses His Father.

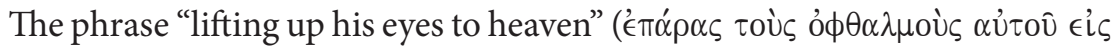
tòv oủpavóv) indicates Jesus' new action in which He turns His face and speech towards the Heavenly Father. Jesus, with His eyes raised to heaven is presented as a divine orant combining earthly matters with heavenly ones. ${ }^{17}$ In the Old Testament (Deut 4:19) Moses, in the name of God, addresses a request, for everyone who raises his eyes to the sky, not to pay idolatrous worship to heavenly bodies created by God. The theme of raising the eyes to the heaven, as the place where God dwells, is known to the Psalmist (Ps 123:1). The Prophet Isaiah often calls upon us to lift up our eyes. ${ }^{18}$ The phrase "lifting up his eyes" occurs in many Old Testament texts and it serves as the announcement of a new action. ${ }^{19}$

${ }^{16}$ See this using in other temps in the Gospel of John: Jn 8:28.26.30; 14:25; 15:11; 16:1.4.6.25.33; 17:1.13.

17 See also the texts: Jn 11:41; Mk 6:41; Lk 18:13; Acts 7:55.

18 Isa 40:26; 49:18; 51:6; 60:4.

19 See: Gen 24:63-64; Ex 14:10; Num 24:2; Deut 4:19; Josh 5:13; Judg 19:17; 2 Sam 13:34; 18,24; 1 Chr 21:16. 
The invocation "Father" introduces the Father - Son relationship. The determination of God as Father has its prehistory in the Old Testament, in Judaism, as well as in some pagan religions. The Heavenly Father - in the mission of Christ - finds a special place also in the Synoptic Gospels. Jesus often turns to God with the call of "Father". ${ }^{20}$ Jesus came into the world to reveal His Father and rebuild the right relation of people to the Father. In the Gospel of John this term occurs 137 times. ${ }^{21}$ The term "Father" occurs repeatedly in the prayer of Jesus (chapter 17). ${ }^{22}$ The Evangelist does not replace the term God with the notion of "Father", but he wishes to show new content in the term. He uses the notion when he quotes Jesus' words or when he considers the relation of Father to Son. While the Synoptics put the emphasis on the Fatherhood of God with regard to people, in the Fourth Gospel the emphasis is very clearly put on the reality of the Father who reveals Himself through the Son. ${ }^{23}$

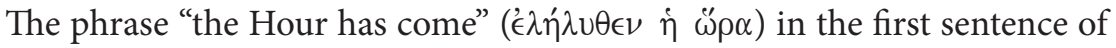
the prayer of Jesus is an introduction to all the interpretative depth related to the issue of the "Hour" of John. The noun "Hour" ( Gospel 25 times in the singular and one time in the plural (Jn 11:9). With few exceptions, the noun is of profound theological significance. The "Hour" of John may mean some period of time during which the saving event takes place: the time of the cult of the Father in the Holy Spirit and the truth ${ }^{24}$; the time of the resurrection of the dead ${ }^{25}$; the time of persecution and dispersion of the disciples. ${ }^{26}$ In the Gospel passage about Cana in Galilee, where Jesus revealed the beginning of His miracles, we also find a mention of the "Hour" which has not come yet (Jn 2:4). St. John, through using this term, creates some tension in his narrative, which consists in waiting for some important event to come. The reality of the "Hour" in the context of the Fourth Gospel emerges as a key to interpret the miracles made by Jesus. The tension characteristic of the Gospel

${ }^{20}$ Mt 11:25; Lk 22:42; 23:34.46; Jn 11:41; 12:27.

${ }^{21}$ See: R. Morgenthaler, Statistik des Neutestamentlichen Wortschatzes, Zürich 1973, p. 130: (Mt - 64 times, Mk - 18 times, Lk - 56 times, Pauline letters - 63 times).

${ }^{22}$ Jn 17:1.5.11.21.24.25.

${ }^{23}$ See: W. Marchel, Ojciec, in: Egzegeza Ewangelii św. Jana, p. 147-156.

${ }^{24}$ Jn $4: 21.25$.

25 Jn 5:25.28.29.

26 Jn 16:2.32. 
of John occurs in Jn 7:30 and Jn 8:20 when "Jews" 27 try to seize Jesus but they cannot do that because His "Hour" has not come yet. It is thus evident that the coming of the "Hour" does not depend on the will of the enemies of Jesus. At the beginning of His prayer in Jn 17:1, Jesus combines the coming of the "Hour" with glorification which accompanies this event. One can see here a close relationship between Jn 12:23 and Jn 17:1:

\begin{tabular}{|c|c|}
\hline Jn 12:23 & Jn 17:1 \\
\hline 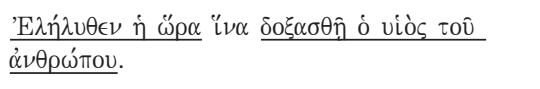 & 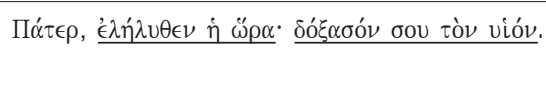 \\
\hline Translation: & Translation: \\
\hline $\begin{array}{l}\text { The Hour has come for the Son of Man to be } \\
\text { glorified. }\end{array}$ & Father, the Hour has come; glorify your Son... \\
\hline
\end{tabular}

The coming of the "Hour" indicates the beginning of Passover - Jesus' leaving earth and going to the Father in Heaven (Jn 13:1 - Jesus knowing that His Hour had come that He should depart out of this world to the Father). The exaltation of Jesus starts upon His entry into the state of humility till the end - till His death on the cross.

At the very beginning of the prayer the Son makes a request to the Father for glorification. The glorification of the Son is here closely connected with the glorification of the Father. In many places in the Gospel of John, the verb "glorify" ( $\delta \circ \xi \alpha \dot{\zeta} \zeta \omega)$ occurs in eschatological sense and it stands for God's acceptance of His Son's glorious death which leads to resurrection and exaltation at the right hand of the Father. The request is not limited only to an appeal to God for help at the moment of death, but the glorification of the Son by the Father constitutes so

${ }^{27}$ We use the quotation marks because this term has in the Johannine narrative specific meaning. See the discussion in: S. Mędala, Funkcja chrystologiczno-eklezjologiczna dialogów Jezusa z Żydami w czwartej Ewangelii, in: Studia z biblistyki, vol. 4, Warszawa 1984; P. Szefler, Żydzi, in: Egzegeza Ewangelii św. Jana, p. 337-346; A. Kuśmirek, Żydzi w Ewangelii Jana, "Studia Theologica Varsaviensia” 30 (1992), p. 121-135; S. Mędala, Funkcja 'Żydów' w Ewangelii św. Jana, "Collectanea Theologica" 64 (1994), p. 79-101; P. Grelot, Les Juifs dans l'évangile selon Jean. Enquête historique et réflexion théologique, Paris 1995; G. Caron, Qui sont les Juifs de l'évangile de Jean?, Ottawa 1997; U. C. Von Vahlde, 'The Jews' in the Gospel of John: Fifteen years of Research (1983-1998), "Ephemerides theologocae Lovanienses" 76 (2000), p. 30-55; M. S. Wróbel, 'Żydzi' Janowi jako klucz interpretacyjny w głębszym rozumieniu historii i teologii czwartej Ewangelii, in: Żydzi i judaizm we wspótczesnych badaniach polskich, ed. K. Pilarczyk, Kraków 2010, p. 47-61. 
to speak the sealing and support of God for actions taken by Jesus. ${ }^{28}$ The Father is also glorified through the Son's glorious and saving action. Consequently, the glorification of the Son is aimed at glorifying the Father. The Son's passion, death and resurrection confirm God's love for mankind. Through His Son's saving action the Father can shine in full radiance in front of the whole creation. The glorification of the Son by the Father and the Father by the Son is a process taking place in the "Hour" of Jesus which goes beyond earthly time and is oriented to eternity (Jn 13:31-32).

v. 2: "Even as you gave him authority over all flesh, that to all whom you have given him, he may give eternal life".

Some phrases in verse 2 have their parallels in the Old Testament text of Sir 17:1-4:

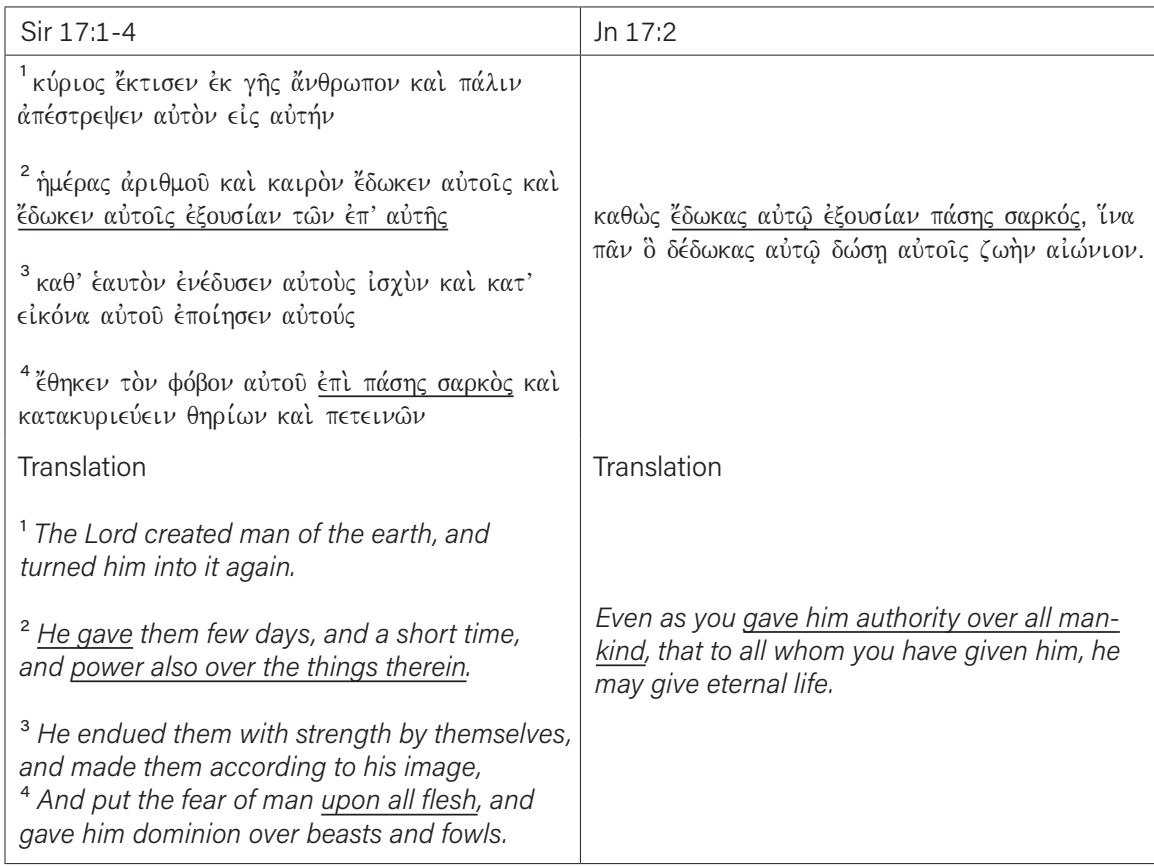

The fragment of the Book of the Wisdom of Sirach refers to the Book of Genesis through emphasizing the fact that God gave man dominion over

${ }^{28}$ Jn $7: 39 ; 11: 4 ; 12: 16.23 ; 13: 31-32 ; 17: 1.5$. See also the use of this verb in: Jn $8: 54 ; 16: 14$; 17:10. 
everything upon the earth. In Jn 17:2 Jesus as a New Adam receives from God power $\left({ }^{\prime} \xi \xi_{0} \sigma \sigma^{\prime} \alpha\right)$ over the whole creation so as to fill it with eternal life ${ }^{29}$. All those who come to Him become His disciples ${ }^{30}$ and receive from Him eternal life. While the first Adam brought death to mankind through his disobedience to God, the New Adam gives eternal life to all believers through His obedience until the very end (Rom 5:17). The verb "to give" ( $\left.\delta \iota^{\prime} \delta \omega \mu \iota\right)$ in Jn 17:2 is used as many as three times. The Father emerges as the One who gives, bestows on the Son. At the same time, the Son gives the same gift to the creation. The term $\delta i \delta \omega \mu \iota$ occurs 76 times in the Gospel of John. ${ }^{31}$ The phrase "to give the life" occurs repeatedly in John's writings. ${ }^{32}$ Power over the whole creation and the disciples of Jesus are the subject of the Father's gift in Jn 17:2. ${ }^{33}$ In Jn 17:4, God's gift is the work handed over to the Son to be completed. The gift is accepted by the Son and executed by Him as the gift of eternal life to mankind (Jn 17:2).

v. 3: "And this is eternal life, that they may know you, the only true God, and Jesus Christ whom you have sent".

The idea of eternal life occurs repeatedly in the Fourth Gospel. ${ }^{34}$ In Jn 17:3 we observe a use of the phrase which is not typical of John. The adjective "eternal" appears before the noun "life" preceded by the definite article. In His prayer Jesus specifies that eternal life consists in getting to know the only, true God and Jesus Christ sent by Him. Using the verb "know" ( $\gamma\llcorner\nu \omega ́ \sigma \kappa \omega)$ in the subjunctive of the present tense expresses a continuous process of getting to know. Combining the idea of eternal life with the reality of cognition finds its parallels in the Jewish wisdom literature ${ }^{35}$. In the Semitic mentality cognition is not confined solely to the intellectual sphere, but it also refers to the sensation and experience of the subject of cognition. For Semitic peoples, cognition is of a dynamic nature which expresses itself in accepting the revelation, and in living in accordance with the accepted revelation. One can see here a connection with the Hebrew

\footnotetext{
${ }^{29}$ M. S. Wróbel, Władza w Ewangelii św. Jana, "Verbum Vitae” 14 (2008), p. 135-152.

30 Jn 17:2.6.9.24.

${ }^{31}$ Morgenthaler, Statistik des Neutestamentlichen Wortschatzes, p. 157: (Mt - 56 times; Mk - 39 times; Lk - 60 times; Pauline Writings - 72 times).

32 Jn 6:33; 10:28; 17:2; 1 J 5:11.16.

${ }^{33}$ See the texts which express the idea of giving the disciples to Jesus by Father: Jn 3:35; $6: 37.39 ; 10: 9 ; 13: 3 ; 17: 2.6 .9 .24 ; 18: 9$.

${ }^{34}$ Jn $3: 15-16.36 ; 4: 14.36 ; 5: 24 ; 6: 27.40 .47 .54 .68 ; 10: 28 ; 12: 25.50 ; 17: 2-3$.

35 Prov 3:18; Wis 15:3.
} 
term ידע. The word $\gamma\left\llcorner\nu \omega ́ \sigma \kappa \omega\right.$ means knowledge gained through experience. ${ }^{36}$ Such a knowledge is often gained in an indirect way which is frequently based on a testimony (Jn 4:53) or experience (Jn 12:9). In the Gospel of John - apart from the verb $\gamma\left\llcorner\nu \omega \sigma \sigma \kappa \omega^{\prime \prime}\right.$ there is also a term oi $\delta \alpha$ used to signify cognition. ${ }^{37}$ In John's writings the verb oi $\delta \alpha$ means knowledge as an absolute matter, an intuitive knowledge which a man possesses without learning, without experience. When analysing the verb $\gamma\llcorner\nu \omega \sigma \sigma \omega \omega$ we conclude that its content is focused on the person of the Father and the Son. Cognition includes sympathy and community. The verb "know", the phrase "eternal life" and the formula "true God" show terminological connections with 1 Jn 5:20 - "And we know that the Son of God has come, and has given us understanding, in order that we might know Him who is true, and we are in Him who is true, in His Son Jesus Christ. This is the true God and eternal life". In the Old Testament the adjective "true" was often used to contrast God with all idols. ${ }^{38}$

In addition to our text, the phrase "Jesus Christ" occurs only once in the Gospel of John (Jn 1:17). When presenting the relationship between God and Jesus Christ, the Author of the Fourth Gospel uses the verb "send" ( $\alpha \pi 0 \sigma \tau \in \epsilon \lambda \omega \omega)$. This term occurs as many as 7 times in chapter 17 alone. ${ }^{39}$ Our text is the only place in the whole of the Fourth Gospel where the formula is explained by apposition. According to some exegetes, the term $\dot{\alpha}^{\pi} \pi 0 \sigma \tau \tau^{\prime} \lambda \lambda \omega$ is used in the Gospel of John with regard to the mission of Jesus to justify His credibility based on the authority of God who sent Him. ${ }^{40}$ Apart from the verb $\dot{\alpha} \pi 0 \sigma \tau \tau^{\prime} \lambda \lambda \omega$ used to signify the idea of mission, the Author of the Fourth Gospel also uses the verb $\pi \in \epsilon \pi \omega$. In most texts of John's Gospel, Father is the subject of this verb. Most often it refers to the relation of the Father to the Son. Very often, there occurs some form of participle. ${ }^{41}$ In the texts where Jesus it pronounces, the phrase is like the proper name of God, who the saving initiative belongs to. God is the "Sending One". Jesus as the sent one gains the authority to act from God, but $\mathrm{He}$ reveals Himself as one with the Father and as the one who participates in the work of the Father. The verb $\pi \epsilon^{\prime} \mu \pi \omega$ is used to show the participation of God

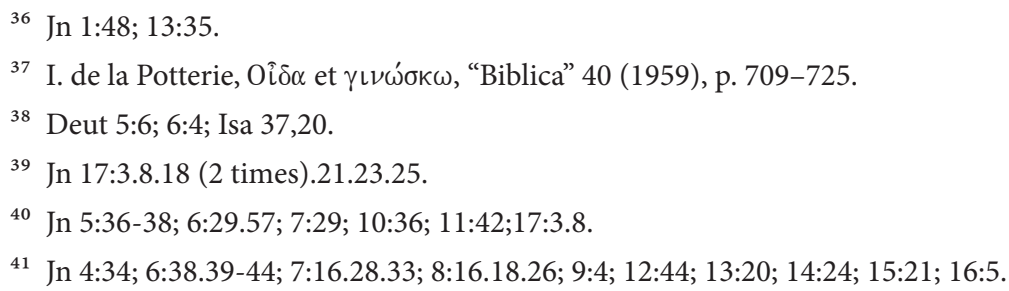


in the work of Jesus in the act of mission. Such an interpretation is consistent with the concept of John, according to which the action of Jesus results from the working of God and through this working of God it accomplishes its objective. It is assumed that the verb $\pi \epsilon \in \pi \omega \omega$ referred to Jesus meaning His mission at the starting point, whereas the verb $\dot{\alpha} \pi 0 \sigma \tau \tau^{\prime} \lambda \lambda \omega$ means the point at which the mission reaches the people, the disciples. The other verb puts the emphasis on the recipient of the mission along with its objective - that they know (Jn 17:3) and that they believe (Jn 8:42.43).

v. 4: "I glorified you on the earth, having accomplished the work which you have given me to do".

The work of the Father is incorporated with the work of the Son. ${ }^{42}$ Jesus is entrusted with the work and He completes it through obedience and love toward

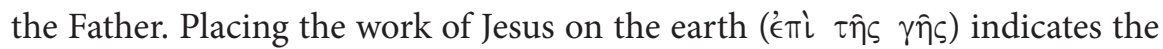
reality of incarnation and Jesus' earthly activities, which prepare Him to enter the heavenly dimension. It is well expressed by v. 5 which refers to Jesus' staying at the side of the Father.

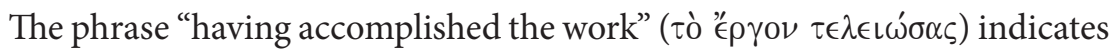
a close relationship between the Father and the Son. In the whole of John's Gospel the verb "accomplish" ( $\tau \in \lambda \in \operatorname{ló} \omega$ ) occurs three times in active voice and always with reference to the work of the Father. ${ }^{43}$ The verb is used in passive voice at the time of crucifying Jesus (Jn 19:28). The work emerges as the gift of the Father to the Son. The gift is fully accepted through its completion. In the completion of the work one can see the action of the Father who bestows and the action of the Son who completes the work. ${ }^{44}$ The actions of the Father and the Son come together into unity and harmony.

v. 5: "And now, glorify you me together with yourself, Father, with the glory which I had with you before the world was".

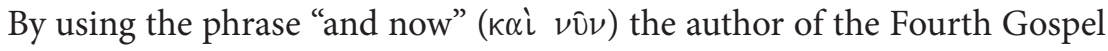
indicates something important, a breakthrough which is happening. In the Old Testament texts the formula often occurs in a juridical and liturgical context. ${ }^{45}$ The Greek preposition $\pi \alpha \rho \alpha$ emphasizes the communion of Jesus with the Father and being in His glory. This form of existence is connected with the exaltation

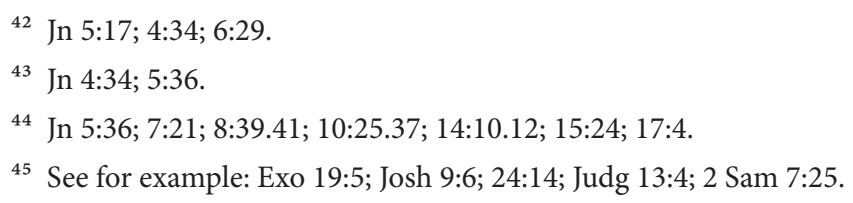


of Jesus at the right hand of the Father. ${ }^{46}$ The Evangelist emphasizes glorification in praise through combining the verb "glorify" ( $\delta \circ \xi \alpha \dot{\alpha} \zeta \omega)$ with the noun "glory" $(\delta o ́ \xi \alpha)$. The glorification of Jesus by God consists in surrounding Him with the praise which $\mathrm{He}$ had had before the world came into being. It is evident here that we have a reference to the idea of pre-existence of Logos in the Prologue to the Gospel of John (Jn 1:1-3). ${ }^{47}$ Verse 5 remains in relation to Jn 17:24, which

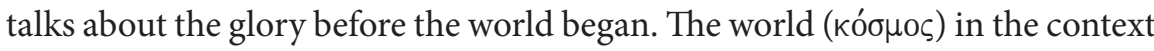
of the idea of pre-existence in Jn 17:5 has a universal meaning and it stands for the whole created universe (Jn 1:10). This term acquires different meanings in the Gospel of John. ${ }^{48}$ Depending on the context it may mean the following: the earth or earthly situation ${ }^{49}$; mankind (Jn 3:16); people who are Satan's subjects, persist in being wrong and angry. Such a world precludes giving oneself to God and accepting His messenger, Christ. Thus, it persecutes Christ with hatred and rejects His proclamation. ${ }^{50}$

\section{Theological proclamation of the prayer of Jesus (Jn 17:1-5)}

The prayer of Jesus has deep theological content. Jesus' invocation at the beginning of the prayer introduces a relationship between the Father and the Son. The relationship is repeatedly emphasized on the pages of the Fourth Gospel. ${ }^{51}$ It is characterized by a strong bond and unity ${ }^{52}$ to such a degree that one can recognize the Father in the Son. ${ }^{53}$ The mission of Jesus is closely incorporated with the Father who sends Him. Jesus teaches and makes miracles in fellowship with the Father Jesus. ${ }^{54}$ The Evangelist presents God the Father as the starting point and the point of reaching the Son. ${ }^{55}$ Jesus tries to do the will of His Father

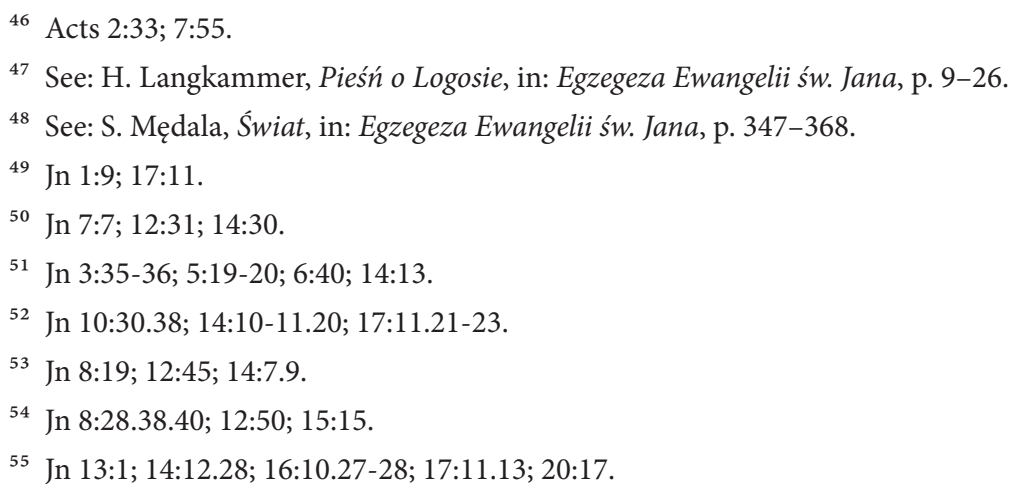


in a perfect way. ${ }^{56}$ It involves glorifying the Father and bestowing eternal life on all those who believe in the Father and in the Son. ${ }^{57}$ Thus, believers become the children of God and together with Jesus they are on their way to the house of the Father. ${ }^{58}$

In the first words of the prayer, Jesus emphasizes the coming of the "Hour". From the theological point of view the event of the "Hour" clearly appears at the level of the relationship between the Father and the Son. Jesus makes the "Hour" - planned by His Father - His own "Hour". The whole life of Jesus is oriented to this "Hour". This raises the question of when the "Hour" of Jesus becomes a reality in the Fourth Gospel? The last period of the earthly life of Jesus begins when the Supreme Jewish Council decides to sentence Jesus to death. ${ }^{59}$ At the very beginning Jesus alludes to His funeral (Jn 12:7). On the next day He clearly says that His "Hour" has come (Jn 12:23). It is evident here that the "Hour", which the Father has at His disposal, is connected with sentencing Jesus to death. Consequently, it is the "Hour" connected with the Passover, the "Hour" of death. Therefore, in a way, Jesus shies away from this very "Hour". In Jn 13:1, there is a concentaration of the whole theology of the coming of the "Hour" (the Passover, passing away from this world, resurrection, the hour of love to the and love to people). In Jn 19:14, the Evangelist specifies the time as six oclock. This is the time of sacrificing the Paschal Lamb. The death of Jesus inaugurates a new Passover. The coming of the "Hour" in John's Gospel is connected with the feast of Passover, the Passion and the glorification of the Son of Man. God's plan of salvation is carried out here. It is also the "Hour" of love until the end. We can observe moments of glory and moments of suffering in the "Hour" (Jn 12:23). Therefore, in the Fourth Gospel the "Hour" means the glorification of the Son of Man through the exaltation on the cross and return to new life through resurrection. Jesus' glorious death reveals glory, the love of the Son and the love of the Father. The realization of the "Hour" of the Father by the Son through the Passion, death and resurrection is connected with His exaltation. At this Hour the earth touches the heights of Heaven with a kiss of love.

Using the verb "to give" in the first part of the prayer (Jn 17:1-5) as many as four times indicates its importance. In the Gospel and in the letters of John

\footnotetext{
${ }^{56}$ Jn $4: 34 ; 8: 29 ; 10: 18 ; 12: 49 ; 14: 31$.

${ }^{57}$ Jn $6: 40 ; 17: 2$.

${ }^{58}$ Jn $12: 26 ; 13: 36 ; 14: 2-3 ; 17: 24$.

${ }^{59}$ Jn 11:53.55; 12:1.
} 
the verb has largely a theological meaning. Giving is a part of God's work in the history of salvation. God's giving comes from the Father. God is the subject of giving in 42 places in the Gospel of John. Subsequently, the gift is passed on to Jesus and through Jesus to people. In the Fourth Gospel the verb indicates the relationship between God the Father and Jesus Christ. It often concerns the total gift which Jesus is fully aware of (Jn 3:35). The gift of God the Father toward Jesus finds its continuation in the gift toward people. The Father's ultimate gift to people is His own Son. The Father's highest love is revealed in the gift of the Son. The word "to give" expresses not only the relationship between the Father and the Son, but also between the Father and the recipients of the gift, namely people. The Father's gift will be continued in Jesus, who receives everything from the Father and passes this gift on to people. The gift of God and the gift of Jesus join into one gift. The unity of the two gifts was revealed in the High Priestly Prayer of Jesus ${ }^{60}$. Every gift has love as its beginning. God has given everything to His Son because He loves Him. God has given the world His only-begotten Son because He so loved the world (Jn 3:16). The word "to give" revealing the relationship between the gift giver - the gift - the gift recipients leads us to the mystery of God and His work for the benefit of people. This is the context in which one should place bestowing eternal life upon mankind through the saving action of Jesus. God the Father attains full and perfect communion of Himself with the world. The request of Jesus to be glorified by the Father is closely connected with the idea of the exaltation of Jesus at the right hand of the Father. ${ }^{61}$ Jesus abiding in the glory of the Father before the creation of the world emerges as the Wisdom of God which presides over the creation of the world. ${ }^{62}$ Jesus becomes the Word of God through which everything comes into being. ${ }^{63}$ The pre-existence of Jesus is strongly emphasized in the fact that $\mathrm{He}$ existed before John the Baptist (Jn 1:30) and before Abraham (Jn 8:58).

Jesus fulfilling the will of His Father is praised with glory. In the Old Testament "the glory of God" manifested itself in His saving action. ${ }^{64}$ The praise is combined in a special way with the sanctuary (Ex 29:43), and later on with the Temple in Jerusalem (1 Kin 8:10). The idea of combining the glory of God with

\footnotetext{
${ }^{60}$ Jn 17:7-8.22.

${ }^{61}$ Ps 110,1; Acts 7,55.

62 Prov 8:22-31; Wis 9:9; Sir 24:9.

${ }^{63}$ Isa 55:10-11; Jn 1:3.14.

${ }^{64}$ Ex 16:7; Num 14:22.
} 
the Temple in Jerusalem is strongly emphasized by prophets. ${ }^{65}$ According to the Fourth Gospel the glory of God is revealed on earth through the person of Jesus, who through the incarnation - as the eternal Logos - took up the residence in a body on earth (Jn 1:14). His appearance is accompanied by glory (Jn 12:40-41). The glory of God is manifested in a special way through the Passion of Jesus, which aims for resurrection and glorification of the Father (Jn 17:4) ${ }^{66}$ Jesus is worshipped in Heaven by God through complete fulfilment of the glorification of His Father on earth. The Gospel also emphasizes the fact that the glory of God manifests itself also through the faith of the disciples, which is a result of preaching the Word of God and making miracles. ${ }^{67}$ The glorification of the Father is closely connected with the worship of the Son. The glorification of the Father (heavenly worship) is shown through the paschal mystery of Jesus and through His exaltation at the right hand of God (Jn 17:1). The glorification of the Son (earthly worship) is fulfilled through the perfection of the work which the Father assigned him to do. The work takes a practical form in the miracles made, in the revelation of God's will, in the revelation of the Truth. The disciples contribute to the glorification of the Father through their faith and the fulfillment of the message of the Son (Jn 15:8). Some authors notice a connection between the beginning of the prayer of Jesus (Jn 17:1-5) and the first part of the Prologue (Jn. 1:1-5). The similarity can be observed in the key to the history of salvation which, in both texts, indicates three basic periods of the history of salvation - The Old Testament, the times of Jesus, the times of the Church. ${ }^{68}$ In the glorification of the Father and the Son one can clearly see the mystery of salvation through combining earthly things with Heaven.

\section{Conclusions}

The analysis of the beginning of the prayer of Jesus (Jn 17:1-5) points out to the fact that it does not have the nature of a request or a call to intercede, but it has the dimension of eschatological glorification of the Father and the Son through the realization of the earthly Hour of Jesus. The prayer invites the reader to go

\footnotetext{
${ }^{65}$ Ezek 9-11; 36:23; Isa 60:1.3.

${ }^{66}$ See: J. Drozd, Chwała Chrystusa, in: Egzegeza Ewangelii św. Jana, p. 167-182.

${ }^{67}$ Jn $2: 11 ; 6: 68-69$.

${ }^{68}$ See: T. Brodie, The Gospel according to John, p. 508-510.
} 
beyond earthly dimensions and enter the "space" of Heaven, to participate in the eternal glory of worship together with Jesus and His Father.

The prayer of Jesus for the eschatological worship by the Father (Jn 17:1.5) closely combines the will of the Father with the actions of the Son, which - though submerged in history - go beyond time toward Heaven in its Alpha and Omega.

The realization of the glorification of the Father by the Son on the earth (Jn 17:4) is accomplished through the complete fulfilment of the work received from the Father. Through the glorious Passion Jesus combines the earth and Heaven, manifesting the love of the Father toward the whole creation.

The glorification of Jesus opens the way of life to all of His followers. Jesus as a New Adam has the power of granting eternal life to all those who accept His message with a living faith and together with Him participate in the glorious worship of the Father.

The prayer of worship of Jesus introduces us to the total extent between the glory of the pre-existence of the Son of God and the eschatological glory at the right hand of the Father. The reality of the incarnation of Jesus and His journey on the earth does not emerge as a way to Heaven across the earth toward Heaven. In the light of the prayer, the history of salvation divided into the Old Testament, the times of Jesus and the times of Church, acquires a new "space" going beyond the beginning and the end. The earthly Jesus, who is born and dies, goes beyond the limits of time and as the glorified Christ He reigns in Heaven.

The prayer of glorification of Jesus opens the earth for Heaven as everyone who raises their eyes to Heaven, and co-operates with the Son in the work of the glorification of the Father during their earthly journey, has an open door to the real life of Heaven and to participation in the glory of the Triune God in the eternal Hour of Glorification.

\section{Bibliography}

Attridge H. W., How priestly is the 'high priestly prayer' of John 17?, "Catholic Biblical Quarterly" 75 (2013), p. 1-14.

Beasley-Murray G. R., John, Nashville: Thomas Nelson 1999.

Becker J., Aufbau, Schichtung und theologiegeschichtliche Stellung des Gebetes in Johannes 17, "Zeitschrift für die neutestamentliche Wissenschaft" 60 (1969), p. 209-232.

Bernard J. H., A Critical and Exegetical Commentary on the Gospel According to St. John, vol. 1-2, Edinburgh: T.\& T. Clark 1949. 
Boismard M.É. - Lamouille, A., L'évangile de Jean, in: Synopse des quatre évangiles en francais, vol. 3, ed. P. Benoit - M. É. Boismard, Paris: Éditions du Cerf 1977.

Brodie T. L., The Gospel according to John. A Literary and Theological Commentary, Oxford: Oxford University Press 1993.

Brown R., The Gospel according to John, vol. 1-2, London: Chapman 1971.

Bultmann R., The Gospel of John, Philadelphia: Westminster Press 1971.

Caron G., Qui sont les Juifs de l'évangile de Jean?, Ottawa: Bellarmin 1997.

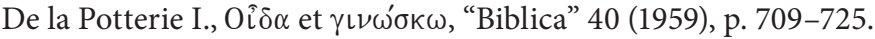

Drozd J., Chwała Chrystusa, in: Egzegeza Ewangelii św. Jana, ed. F. Gryglewicz, Lublin: Redakcja Wydawnictw KUL 1992, p. 167-182.

Grelot P., Les Juifs dans l'évangile selon Jean. Enquête historique et réflexion théologique, Paris: Gabalda et $\mathrm{C}^{\text {ie }}$ Éditeurs 1995.

Gryglewicz F., Modlitwa Arcykapłańska, in: Egzegeza Ewangelii św. Jana, ed. F. Gryglewicz, Lublin: Redakcja Wydawnictw KUL 1992, p. 113-146.

Hera M. P., Christology and discipleship in John 17, Tübingen: Mohr Siebeck 2013.

Käsemann E., Jesu letzter Wille nach Johannes 17, Tübingen: Mohr Siebeck 1971.

Kuśmirek A., Żydzi w Ewangelii Jana, "Studia Theologica Varsaviensia” 30 (1992), p. 121-135.

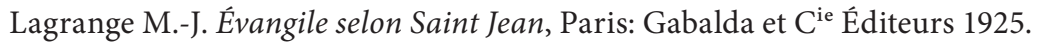

Langkammer H., Pieśń o Logosie, in: Egzegeza Ewangelii św. Jana, ed. F. Gryglewicz, Lublin: Redakcja Wydawnictw KUL 1992, p. 9-26.

Léon-Dufour X., Lecture de l'évangile selon Jean, vol. 1-4, Paris: Éditions du Seuil 1988-1996.

Manns F., L'Évangile de Jean à la lumière du Judaïsme, Jerusalem: Franciscan Printing Press 1991, p. 383-400.

Marchel W., Ojciec, in: Egzegeza Ewangelii św. Jana, ed. F. Gryglewicz, Lublin: Redakcja Wydawnictw KUL 1992, p. 147-156.

Mędala S., Funkcja chrystologiczno-eklezjologiczna dialogów Jezusa z Żydami w czwartej Ewangelii, in: Studia z biblistyki, vol. 4, Warszawa: Akademia Teologii Katolickiej 1984.

Mędala S., Świat, in: Egzegeza Ewangelii św. Jana, ed. F. Gryglewicz, Lublin: Redakcja Wydawnictw KUL 1992, p. 347-368.

Mędala S., Funkcja 'Żydów' w Ewangelii św. Jana, “Collectanea Theologica” 64 (1994), p. 79-101.

Morgenthaler R., Statistik des Neutestamentlichen Wortschatzes, Zürich: Gotthelf Verlag 1973.

Schnackenburg R., Strukturanalyse von Joh 17, "Biblische Zeitschrift” 17 (1973), p. 67-78.

Schanckenburg R., The Gospel according to St. John, vol. 1-3, London: Burns and Oates 1982.

Stachowiak L., Modlitwa arcykapłańska (J 17). Refleksja egzegetyczna, "Roczniki Teologiczno-Kanoniczne” 21 (1974), p. 85-94. 
Szefler P., Żydzi, in: Egzegeza Ewangelii św. Jana, ed. F. Gryglewicz, Lublin: Redakcja Wydawnictw KUL 1992, p. 337-346.

Tolmie D. F., Jesus' Farewell to the Disciples: John 13:1-17:26 in Narratological Perspective, Leiden: Brill 1995.

Von Vahlde U. C., 'The Jews' in the Gospel of John: Fifteen years of Research (1983-1998), "Ephemerides theologicae Lovanienses" 76 (2000), p. 30-55.

Wróbel M. S., Władza w Ewangelii św. Jana, "Verbum Vitae" 14 (2008), p. 135-152.

Wróbel M. S., 'Żydzi' Janowi jako klucz interpretacyjny w głębszym rozumieniu historii i teologii czwartej Ewangelii, in: Żydzi i judaizm we współczesnych badaniach polskich, ed. K. Pilarczyk, Kraków: Antykwa 2010, p. 47-61. 